\title{
The role of anti-EGFR agents in the first-line treatment of advanced esophago-gastric adenocarcinoma: a meta-analysis
}

\author{
Bum Jun Kim ${ }^{1,2, *}$, Jung Han Kim ${ }^{1, *}$, Hyun Joo Jang ${ }^{3}$ and Hyeong Su Kim ${ }^{1}$ \\ ${ }^{1}$ Division of Hemato-Oncology, Department of Internal Medicine, Kangnam Sacred-Heart Hospital, Hallym University Medical \\ Center, Hallym University College of Medicine, Seoul 07441, Republic of Korea \\ ${ }^{2}$ Department of Internal Medicine, National Army Capital Hospital, The Armed Forces Medical Command, Seongnam 13574, \\ Republic of Korea \\ ${ }^{3}$ Division of Gastroenterology, Department of Internal Medicine, Dongtan Sacred-Heart Hospital, Hallym University Medical \\ Center, Hallym University College of Medicine, Hwasung 18450, Republic of Korea \\ *These authors contributed equally to this work \\ Correspondence to: Jung Han Kim, email: harricil@hotmail.com \\ Hyun Joo Jang, email: jhj1229@hallym.or.kr
}

Keywords: esophageal cancer, gastric cancer, anti-EGFR agent, meta-analysis

Received: May 16, 2017 Accepted: August 28, $2017 \quad$ Published: September 16, 2017

Copyright: Kim et al. This is an open-access article distributed under the terms of the Creative Commons Attribution License 3.0 (CC BY 3.0), which permits unrestricted use, distribution, and reproduction in any medium, provided the original author and source are credited.

\section{ABSTRACT}

The role of anti-epidermal growth factor receptor (EGFR) therapy is controversial in patients with esophago-gastric adenocarcinoma. We performed this meta-analysis to evaluate whether the addition of an anti-EGFR agent to chemotherapy can produce survival benefits in patients with advanced esophageal adenocarcinoma, gastric adenocarcinoma, or gastroesophageal junction adenocarcinoma. Electronic databases were searched for eligible randomized studies. From six studies, 1,817 patients were included in the meta-analysis of hazard ratios (HRs) for progression-free survival (PFS) and overall survival (OS). Compared with chemotherapy alone, anti-EGFR agents in combination with chemotherapy were significantly associated with shorter PFS (HR $=1.14[95 \%$ confidence interval $\{C I\}, 1.01-1.28], P=0.03)$. In terms of OS, the addition of an anti-EGFR agent to chemotherapy showed no advantage (HR $=1.10[95 \% \mathrm{CI}, 0.98-1.23], P=0.11)$. In addition, the combination of an anti-EGFR agent with chemotherapy significantly increased some grade $3 / 4$ toxicities including diarrhea (risk ratio $\{R R\}=1.42,[95 \% C I, 1.03-1.94], P=0.03)$, mucositis $(R R=3.30$ [95\% CI, 1.54-7.07], $P=0.002)$, and skin rash $(R R=6.82[95 \% C I, 3.15-14.78]$, $P<0.00001)$. In conclusion, this meta-analysis indicates that the addition of an antiEGFR agent to chemotherapy conveys no additional benefit for patients with advanced esophago-gastric adenocarcinoma. As of now, anti-EGFR agents should not be used in the first-line treatment of adenocarcinoma of the upper gastrointestinal tract.

\section{INTRODUCTION}

Gastric cancer and esophageal cancer are one of the common cancers worldwide, in terms of incidence as well as mortality $[1,2]$. Radical surgery with or without perioperative or adjuvant treatment offers a potential chance of cure for patients with localized disease; however a considerable number of patients present with advanced disease at the time of diagnosis. Moreover, more than half of the patients treated with complete resection develop recurrence within five years after surgery $[3,4]$. For patients with advanced or metastatic diseases, combination chemotherapy can prolong median overall survival (OS) from 3-4 months to approximately 10-13 months with best supportive care $[5,6]$. Despite the introduction of new therapeutic regimens, however, the five-year survival rate is still less than $10 \%$; therefore, the development of more efficacious treatments is needed.

Epidermal growth factor receptor (EGFR) is overexpressed in more than $30 \%$ of gastric adenocarcinoma 
(GAC) and esophageal adenocarcinoma (EAC) cases $[7,8]$. The overexpression of EGFR and its association with a poor prognosis provide a rationale for the use of anti-EGFR agents in patients with advanced or metastatic EAC or GAC. Anti-EGFR antibodies are molecularly targeted agents that exhibit anti-tumor activity by blocking a cascade of signal transduction pathway. In patients with metastatic colorectal cancer, the addition of targeted agents such as cetuximab and panitumumab to standard chemotherapy significantly improves OS $[9,10]$. Then, anti-EGFR therapy has also received a great attention in esophageal or gastric cancer, and various antiEGFR agents have been tested in randomized controlled trials [11-20]. The addition of an anti-EGFR agent to chemotherapy did not significantly enhance progressionfree survival (PFS) and OS in patients with squamous cell carcinoma (SCC) of the esophagus and gastroesophageal junction $[11,12]$. However, the role of anti-EGFR therapy is controversial in patients with adenocarcinoma of the esophagus or stomach.

We performed this meta-analysis of randomized trials to evaluate whether the addition of an anti-EGFR agent to chemotherapy can produce survival benefits in patients with advanced EAC, GAC, or gastroesophageal junction adenocarcinoma (GEJAC).

\section{RESULTS}

\section{Results of search}

The flowchart of our study is shown in Figure 1. A total of 450 potentially relevant studies were identified by our searching strategy; 437 were excluded after carefully screening the titles and abstracts. Of the remaining 13 prospective studies, 7 were further excluded by the inclusion criteria: two randomized trials consisted of patients mainly with esophageal SCC [11, 12] and other two conducted in a salvage treatment setting were excluded $[13,14]$. Finally, six randomized clinical trials were included in this meta-analysis [15-20].

\section{Characteristics of the eligible studies}

Table 1 summarizes the main characteristics of the six included studies. Three studies were conducted in patients with GAC or GEJAC $[16,17,19]$ and the other three in patients with EAC, GAC, or GEJAC $[15,18,20]$. In one study with 77 patients, $5(6.5 \%)$ with esophageal SCC were also included [20]. There were two phase III trials $[16,18]$ and four phase II trials $[15,17$, $19,20]$. The included studies were all conducted in the firstline treatment setting for patients with advanced esophagogastric cancer. The anti-EGFR agents used included matuzumab [15], cetuximab [16, 17], panitumumab $[18,20]$, and nimotuzumab [19].

\section{Survival}

From the six studies [15-20], 1,817 patients were included in the meta-analysis of hazard ratios (HRs) for PFS and OS. Compared with chemotherapy alone, antiEGFR agents in combination with chemotherapy were significantly associated with a shorter PFS $(\mathrm{HR}=1.14$ [95\% confidence interval $\{\mathrm{CI}\}, 1.01-1.28], P=0.03$ ) (Figure 2A). We adopted the fixed-effects model because there was no significant heterogeneity $\left(X^{2}=7.12, P=0.21\right.$, $\left.I^{2}=30 \%\right)$.

In terms of OS, the addition of an anti-EGFR agent to chemotherapy showed no advantage $(\mathrm{HR}=1.10$ [95\% CI, 0.98-1.23], $P=0.11$ ) (Figure 2B). We also used the fixed-effects model because there was no significant heterogeneity $\left(X^{2}=9.03, P=0.11, I^{2}=45 \%\right)$.

\section{Adverse events}

Omitting the REAL3 trial with the different doses of chemotherapeutic drugs between two arms [18], the five studies $[15-17,19,20]$ were included in the meta-analysis of adverse events (AEs). Table 2 shows the estimated risk ratios (RRs) of common AEs. The addition of an antiEGFR agent to chemotherapy significantly increased some grade $3 / 4$ toxicities including diarrhea $(\mathrm{RR}=1.42$, [95\% CI, 1.03-1.94], $P=0.03$ ), mucositis ( $\mathrm{RR}=3.30$ [95\% CI, 1.54-7.07], $P=0.002)$, and skin rash $(\mathrm{RR}=6.82[95 \%$ CI, 3.15-14.78], $P<0.00001)$. Hypokalemia and asthenia tended to occur more frequently when an anti-EGFR agent was added to chemotherapy. Interestingly, however, the addition of an anti-EGFR agent significantly reduced the rate of grade $3 / 4$ neutropenia $(\mathrm{RR}=0.68[95 \% \mathrm{CI}$, 0.52-0.89], $P=0.004)$.

\section{Publication bias}

Visual inspection of the funnel plots and Egger's test for PFS $(P=0.152)$ and $\operatorname{OS}(P=0.087)$ indicated that there were no substantial publication biases (Figure 3A and $3 \mathrm{~B})$.

\section{DISCUSSION}

Several meta-analyses already reported that antiEGFR combination therapy did not improve PFS and OS in patients with esophago-gastric cancers [21, 22]. However, those studies had major limitations that patients with SCC of the upper esophagus or patients with various treatment settings were included in the analysis. In the current study, we investigated the role of anti-EGFR targeted agents in the first-line treatment setting for patients with advanced/metastatic EAC, GAC or GEJAC. The meta-analysis of six randomized studies revealed that the addition of an anti-EGFR agent to chemotherapy led 
Table 1: Summary of the six included studies

\begin{tabular}{|c|c|c|c|c|c|c|c|c|c|c|}
\hline $\begin{array}{l}\text { Author, } \\
\text { trial name (year) }\end{array}$ & $\begin{array}{l}\text { Phase, } \\
\text { Setting }\end{array}$ & $\begin{array}{l}\text { Primary } \\
\text { site }\end{array}$ & $\begin{array}{l}\text { No. of } \\
\text { patients }\end{array}$ & Treatment arms & $\begin{array}{l}\text { Primary } \\
\text { endpoint }\end{array}$ & ORR & $\begin{array}{c}\text { mPFS } \\
(\mathrm{mo})\end{array}$ & $\begin{array}{l}\text { HR for PFS } \\
(95 \% \mathrm{CI})\end{array}$ & $\begin{array}{r}\mathrm{mOS} \\
(\mathbf{m o})\end{array}$ & $\begin{array}{l}\text { HR for OS } \\
(95 \% \mathrm{CI})\end{array}$ \\
\hline \multirow[t]{2}{*}{$\begin{array}{l}\text { Rao et al., } \\
(2010)\end{array}$} & $\begin{array}{l}\text { II } \\
\text { 1st-line }\end{array}$ & $\mathrm{E} / \mathrm{GEJ} / \mathrm{S}$ & 35 & $\begin{array}{l}\text { Epirubicin } 50 \mathrm{mg} / \mathrm{m}^{2}+\text { cisplatin } 60 \mathrm{mg} / \mathrm{m}^{2} \text { on day } 1+ \\
\text { capecitabine } 1250 \mathrm{mg} / \mathrm{m}^{2} \text { daily on days } 1-21 \text { and matuzumab } \\
800 \mathrm{mg} \text { weekly }\end{array}$ & ORR & $31 \%$ & 4.8 & $\begin{array}{l}1.13(0.63-2.01) \\
P=0.678\end{array}$ & 9.4 & $\begin{array}{l}1.02(0.61-1.70) \\
\quad P=0.945\end{array}$ \\
\hline & & & 36 & Same without matuzumab & & $58 \%$ & 7.1 & & 12.2 & \\
\hline \multirow[t]{2}{*}{$\begin{array}{l}\text { Lordick } \text { et al., } \\
\text { EXPAND (2013) }\end{array}$} & $\begin{array}{l}\text { III } \\
\text { 1st-line }\end{array}$ & $\mathrm{GEJ} / \mathrm{S}$ & 455 & $\begin{array}{l}\text { Capecitabine } 1000 \mathrm{mg} / \mathrm{m}^{2} \text { on days } 1-14+\text { cisplatin } 80 \mathrm{mg} / \\
\mathrm{m}^{2} \text { on day } 1 \mathrm{q} 3 \mathrm{wks}+\text { cetuximab } 400 \mathrm{mg} / \mathrm{m}^{2} \text { on day } 1 \text { (first), } \\
\text { then } 250 \mathrm{mg} / \mathrm{m}^{2} \text { weekly }\end{array}$ & PFS & $30 \%$ & 4.4 & $\begin{array}{c}1.09(0.92-1.29) \\
P=0.32\end{array}$ & 9.4 & $\begin{array}{c}1.00(0.87-1.17) \\
P=0.95\end{array}$ \\
\hline & & & 449 & Same without cetuximab & & $29 \%$ & 5.6 & & 10.7 & \\
\hline \multirow[t]{2}{*}{$\begin{array}{l}\text { Richards et al., } \\
(2013)\end{array}$} & $\begin{array}{l}\text { II } \\
\text { 1st-line }\end{array}$ & $\mathrm{GEJ} / \mathrm{S}$ & 75 & $\begin{array}{l}\text { Docetaxel } 60 \mathrm{mg} / \mathrm{m}^{2}+\text { oxaliplatin } 130 \mathrm{mg} / \mathrm{m}^{2} \text { on day } \\
1 \mathrm{q} 3 \mathrm{wks}+\text { cetuximab } 400 \mathrm{mg} / \mathrm{m}^{2} \text { on day } 1 \text { (first), then } \\
250 \mathrm{mg} / \mathrm{m}^{2} \text { weekly }\end{array}$ & PFS & $38.0 \%$ & 5.1 & $\begin{array}{l}0.85(0.57-1.28) \\
\quad P=0.445\end{array}$ & 9.4 & $\begin{array}{l}0.92(0.64-1.34) \\
\quad P=0.663\end{array}$ \\
\hline & & & 75 & Same without cetuximab & & $26.5 \%$ & 4.7 & & 8.5 & \\
\hline \multirow[t]{2}{*}{$\begin{array}{l}\text { Waddell et al., } \\
\text { REAL3 } \\
(2013)\end{array}$} & $\begin{array}{l}\text { III } \\
\text { 1st-line }\end{array}$ & $\mathrm{E} / \mathrm{GEJ} / \mathrm{S}$ & 278 & $\begin{array}{l}\text { Epirubicin } 50 \mathrm{mg} / \mathrm{m}^{2}+\text { oxaliplatin } 100 \mathrm{mg} / \mathrm{m}^{2} \text { on day } 1 \text { and } \\
\text { capecitabine } 1000 \mathrm{mg} / \mathrm{m}^{2} \text { on days } 1-21+\text { panitumumab } \\
9 \mathrm{mg} / \mathrm{kg} \text { on day } 1 \mathrm{q} 3 \mathrm{wks}\end{array}$ & OS & $46 \%$ & 6.0 & $\begin{array}{c}1.22(0.98-1.52) \\
P=0.068\end{array}$ & 8.8 & $\begin{array}{c}1.37(1.07-1.76) \\
P=0.13\end{array}$ \\
\hline & & & 275 & $\begin{array}{l}\text { Epirubicin } 50 \mathrm{mg} / \mathrm{m}^{2}+\text { oxaliplatin } 130 \mathrm{mg} / \mathrm{m}^{2} \text { on day } 1 \text { and } \\
\text { capecitabine } 1250 \mathrm{mg} / \mathrm{m}^{2} \text { on days } 1-21 \mathrm{q} 3 \mathrm{wks}\end{array}$ & & $42 \%$ & 7.4 & & 11.3 & \\
\hline \multirow[t]{2}{*}{$\begin{array}{l}\text { Du et al., } \\
\text { (2015) }\end{array}$} & $\begin{array}{l}\text { II } \\
\text { 1st-line }\end{array}$ & $\mathrm{GEJ} / \mathrm{S}$ & 31 & $\begin{array}{l}\text { S-1 } 80 \mathrm{mg} / \mathrm{m}^{2} \text { on days } 1-14 \text { and cisplatin } 30 \mathrm{mg} / \mathrm{m}^{2} \text { on days } \\
1 \& 2 \mathrm{q} 3 \mathrm{wks}+\text { weekly nimotuzumab } 200 \mathrm{mg} / \mathrm{m}^{2}\end{array}$ & ORR & $54.8 \%$ & 4.8 & $\begin{array}{l}2.14(1.19-3.83) \\
\quad P=0.011\end{array}$ & 10.2 & $\begin{array}{c}1.78(0.97-3.25) \\
P=0.062\end{array}$ \\
\hline & & & 31 & Same without nimotuzumab & & $58.1 \%$ & 7.2 & & 14.3 & \\
\hline \multirow[t]{2}{*}{$\begin{array}{l}\text { Tebbutt et al., } \\
\text { ATTAX3 } \\
\text { (2016) }\end{array}$} & $\begin{array}{l}\text { II } \\
\text { 1st-line }\end{array}$ & $\mathrm{E} / \mathrm{GEJ} / \mathrm{S}$ & 38 & $\begin{array}{l}\text { Docetaxel } 30 \mathrm{mg} / \mathrm{m}^{2} \text { on days } 1 \& 8+\text { cisplatin } 60 \mathrm{mg} / \mathrm{m}^{2} \text { on } \\
\text { day } 1+5-\mathrm{FU} 160 \mathrm{mg} / \mathrm{m}^{2} \text { daily or capecitabine } 1000 \mathrm{mg} / \mathrm{m}^{2} \\
\text { daily q } 3 \mathrm{wks}+\text { panitumumab } 9 \mathrm{mg} / \mathrm{m}^{2} \text { on day } 1\end{array}$ & ORR & $58 \%$ & 6.0 & $\begin{array}{l}1.14(0.68-1.91) \\
P=0.614\end{array}$ & 10.0 & $\begin{array}{c}1.49(0.83-2.67) \\
P=0.183\end{array}$ \\
\hline & & & 39 & Same without panitumumab & & $49 \%$ & 6.9 & & 11.7 & \\
\hline
\end{tabular}

E, esophagus; GEJ, gastroespophageal junction; S, stomach; 5-FU, 5-fluorouracil; ORR, overall response rate; CI, confidence interval; mOS, median overall survival; mPFS, median progression-free survival; HR, hazard ratio; wks, weeks; NA, not available.

to no improvement of PFS and OS with a potential risk of increasing severe AEs.

The poor outcomes associated with the addition of an anti-EGFR agent to chemotherapy were not attributable to increased treatment-related deaths; therefore, other potential hypotheses need to be considered. First, the lack of additional benefit of anti-EGFR agents might be in part due to the reduction of dose intensity of chemotherapy in response to AEs. In this meta-analysis, the addition of an anti-EGFR agent significantly increased some grade 3/4 AEs including diarrhea, mucositis, and skin rash. Thus, these severe toxicities may serve to reduce the dose intensity of chemotherapy in the experimental group with an anti-EGFR agent. In the REAL3 study, the addition of

Potentially relevant studies identified through database searching $(\mathrm{n}=450)$

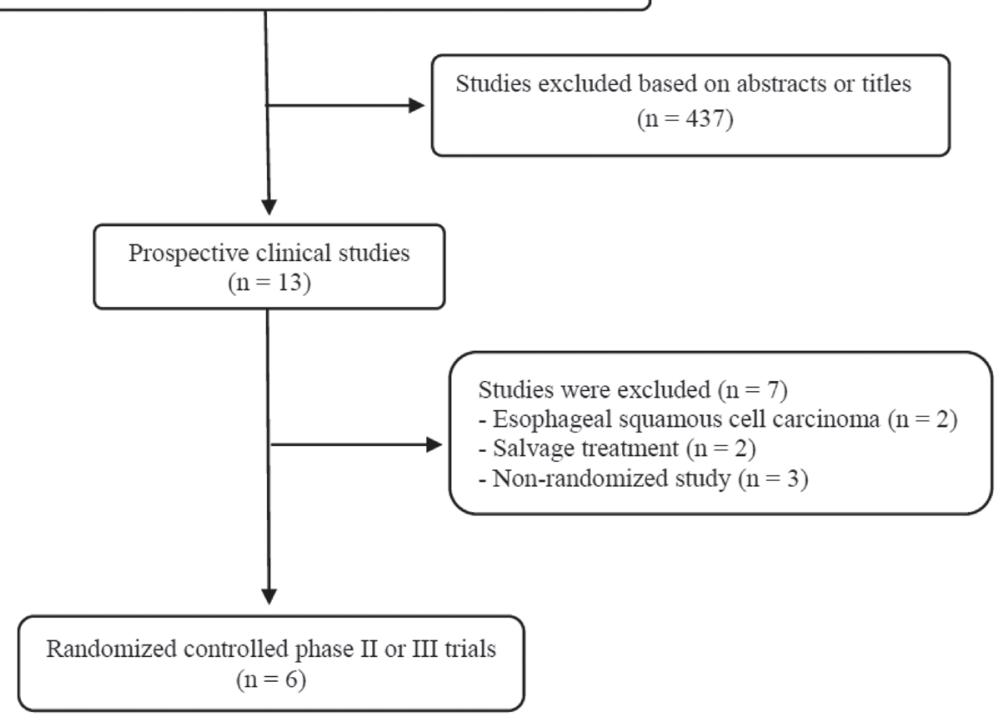

Figure 1: Flow diagram of search process. 
Table 2: The estimated risk ratio (RR) for common grade 3/4 adverse events

\begin{tabular}{|c|c|c|c|c|c|c|c|c|c|}
\hline \multirow[b]{2}{*}{ Adverse events } & \multicolumn{3}{|c|}{$\begin{array}{l}\text { Anti-EGFR agent } \\
+ \text { chemotherapy }\end{array}$} & \multicolumn{4}{|c|}{ Chemotherapy } & \multirow[b]{2}{*}{$\boldsymbol{P}$} & \multirow[b]{2}{*}{ RR (95\% CI) } \\
\hline & Total & Events & $\%$ & Total & Events & $\%$ & $I^{2}$ & & \\
\hline Neutropenia & 597 & 148 & 24.8 & 571 & 233 & 40.8 & $19 \%$ & 0.004 & $0.68(0.52-0.89)$ \\
\hline Anemia & 512 & 43 & 8.4 & 503 & 51 & 10.1 & $0 \%$ & 0.32 & $0.81(0.53-1.23)$ \\
\hline Thrombocytopenia & 549 & 25 & 4.6 & 535 & 27 & 5.0 & $0 \%$ & 0.63 & $0.87(0.49-1.53)$ \\
\hline Febrile neutropenia & 144 & 17 & 11.8 & 143 & 15 & 10.5 & $0 \%$ & 0.75 & $1.13(0.53-2.44)$ \\
\hline Diarrhea & 590 & 58 & 9.8 & 579 & 33 & 5.7 & $0 \%$ & 0.007 & $1.85(1.18-2.91)$ \\
\hline Mucositis & 483 & 29 & 6.0 & 475 & 9 & 1.9 & $0 \%$ & 0.002 & $3.30(1.54-7.07)$ \\
\hline Vomiting & 518 & 39 & 7.5 & 511 & 42 & 8.2 & $0 \%$ & 0.71 & $0.92(0.58-1.44)$ \\
\hline Asthenia & 590 & 66 & 11.2 & 579 & 47 & 8.1 & $0 \%$ & 0.07 & $1.45(0.97-2.16)$ \\
\hline Hypokalemia & 481 & 58 & 12.1 & 472 & 41 & 8.7 & $0 \%$ & 0.09 & $1.44(0.95-2.19)$ \\
\hline Neuropathy & 107 & 9 & 8.4 & 104 & 7 & 6.7 & $0 \%$ & 0.65 & $1.28(0.44-3.67)$ \\
\hline Skin rash & 590 & 90 & 15.3 & 579 & 11 & 1.9 & $50 \%$ & $<0.00001$ & $6.82(3.15-14.78)$ \\
\hline Hand-foot syndrome & 518 & 35 & 6.8 & 511 & 16 & 3.1 & $66 \%$ & 0.72 & $1.29(0.32-5.29)$ \\
\hline Cardiac events & 481 & 31 & 6.4 & 472 & 22 & 4.7 & $56 \%$ & 0.98 & $1.02(0.36-2.85)$ \\
\hline Death & 481 & 43 & 8.9 & 472 & 36 & 7.6 & $0 \%$ & 0.45 & $1.19(0.75-1.89)$ \\
\hline
\end{tabular}

panitumumab to chemotherapy (epirubicin, oxaliplatin, and capecitabine) was initially observed to be toxic [18]. After reducing the doses of oxaliplatin and capecitabine in the experimental group, patients receiving panitumumab plus the modified chemotherapy showed worse OS, compared with those in the control group ( 8.8 vs. 11.3 months, $P=0.013$ ). However, there was no significant difference in the dose intensity of chemotherapeutic agents between two arms in other four studies included in this meta-analysis $[15,16,19,20]$

Second, the absence of efficacy might be attributable to a negative pharmacokinetic interaction between antiEGFR agents and chemotherapeutic agents [23, 24]. Out of the six studies included in this meta-analysis, four used capecitabine. In a meta-analysis of four randomized studies with colorectal cancer patients, only patients

A

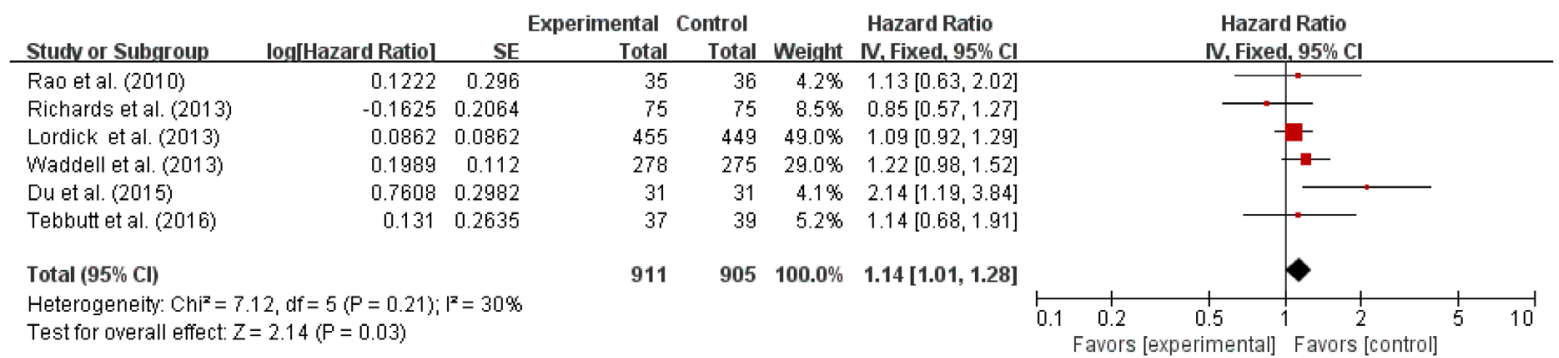

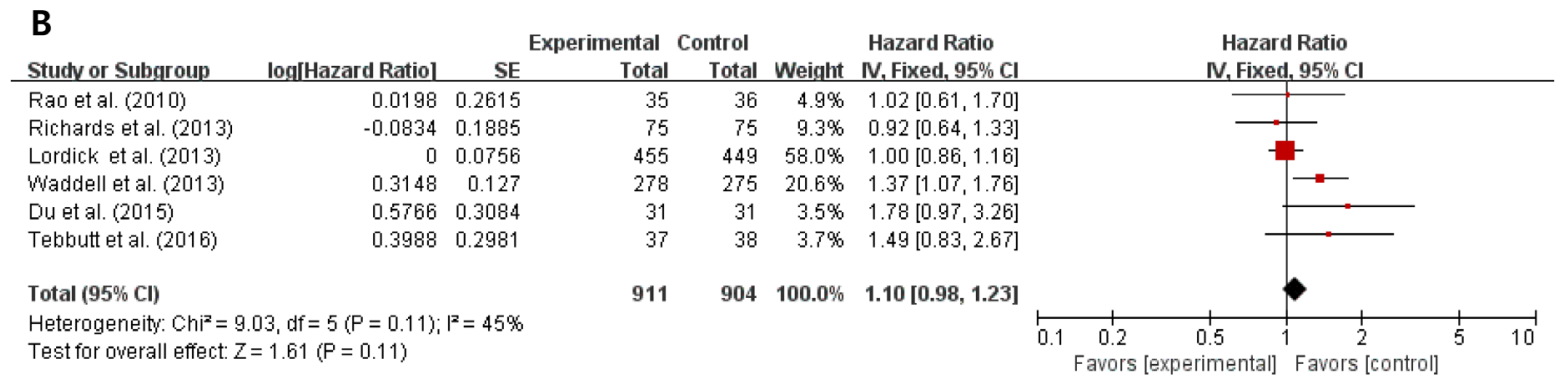

Figure 2: Forest plots of hazard ratios regarding progression-free survival (A) and overall survival (B). 
treated with infusional 5-fluorouracil (5-FU)-based chemotherapy derived benefit from cetuximab [23]. Compared with patients treated with infusional 5-FU, those who received capecitabine or bolus 5-FU showed a $42 \%$ decrease in response probability $(P<0.001)$ and a $52 \%(P<0.001)$ and $33 \%(P=0.012)$ increase in the risk of progression and death, respectively. These results suggest that the interactions between anti-EGFR agents and cytotoxic agents may affect their efficacy as well as toxicity.

Third, KRAS mutation status can also affect the efficacy of anti-EGFR therapy. In patients with metastatic colorectal cancer, KRAS mutation is a negative predictive marker for anti-EGFR therapy. However, the expected frequency of $K R A S$ mutation is only approximately $3 \%$ in EACs or GACs [25-27]. In this meta-analysis, the relevant data was insufficient to analyze the impact of $K R A S$ mutation on drug efficacy because mutational status was assessed only in a small portion of patients.

To increase efficacy and avoid unnecessary toxicities, discovering other predictive biomarkers to identify the correct candidates for anti-EGFR therapy is essential for patients with advanced or metastatic esophago-gastric cancer. Several studies in these cancers have suggested that EGFR expression, EGFR gene copy number, or expression of other EGFR ligands (epiregulin and amphiregulin) might be potential biomarkers for efficacy of anti-EGFR antibodies [27-29]. The EGFR expression level was a predictive marker of survival benefits in advanced non-small-cell lung cancer patients treated with cetuximab and first-line chemotherapy [30]. In the EXPAND study, however, EGFR immunohistochemistry score was not associated with PFS or OS in either treatment group [16]. Further translational studies, with respect to candidate biomarkers, are required before considering anti-EGFR therapy for those patients.

Of note, our study has several limitations. First, the small number of included studies is a major limitation of this meta-analysis. Second, the individual studies

A

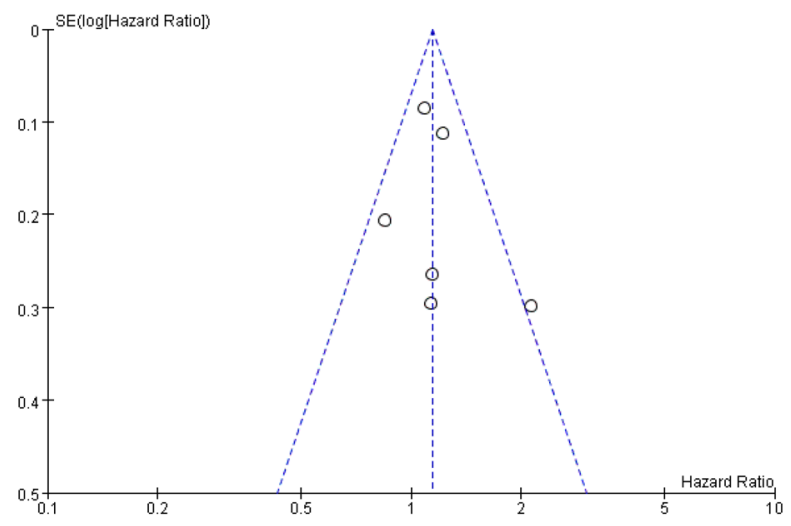

enrolled cancer patients with different primary sites (low esophagus, gestroesophageal junction, and stomach). Third, the experimental group used different anti-EGFR agents (catuximab, panitumumab, matuzumab, and nimotuzumab). Finally, as we mentioned above, one study included five patients with esophageal SCC; however, because they occupied only a small portion of patients, inclusion of these patients did not seem to affect the results.

In conclusion, this meta-analysis indicates that the addition of an anti-EGFR agent to chemotherapy conveys no additional benefit for patients with advanced EAC, GAC, or GEJAC. As of now, anti-EGFR antibodies should not be used in the treatment of adenocarcinoma of the upper gastrointestinal tract. Translational studies to explore predictive biomarkers are warranted to identify ideal candidates of anti-EGFR therapy.

\section{MATERIALS AND METHODS}

\section{Searching strategy}

This study was carried out in accordance with the Preferred Reporting Items for Systematic Reviews and Meta-Analyses (PRISMA) guidelines [31]. The electronic databases PubMed, EMBASE, and Clinical Trials (ClinicalTrials.gov) up to December 2016 were systematically searched. We also manually searched the following congress abstract databases: American Society for Clinical Oncology (ASCO) Annual Meeting, ASCO Gastrointestinal Cancers Symposium, and European Society for Medical Oncology (ESMO) Congress. The search was performed using the following terms: "gastric cancer," "gastroesophageal junction cancer," "esophageal cancer," "randomized," "anti-EGFR or anti-epidermal growth factor receptor," "cetuximab," "panitumumab," "matuzumab," "nimotuzumab," "gefitinib," "erlotinib," or "vandetanib" in various combinations. The related articles function in PubMed was also used to identify all related articles.

\section{B}

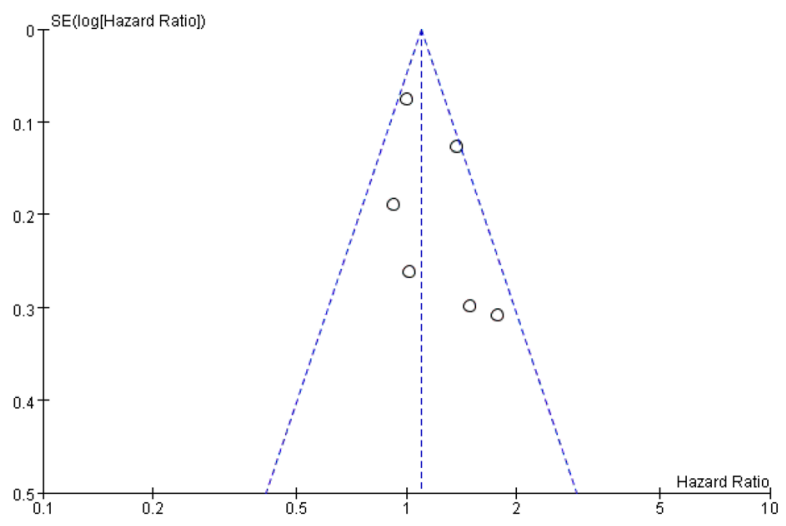

Figure 3: Funnel plots for publication bias test regarding progression-free survival (A) and overall survival (B). 


\section{Inclusion and exclusion criteria}

Eligible studies were required to meet the following inclusion criteria: (i) prospective randomized, controlled trials in patients with advanced/metastatic adenocarcinoma of the esophagus, gastroesophageal junction, or stomach; (ii) randomization of chemotherapy-naïve patients to either anti-EGFR agent plus chemotherapy or chemotherapy alone; (iii) HRs and their $95 \%$ CIs for PFS or OS were reported or could be calculated from the data provided.

The studies consisting mainly of patients with squamous cell carcinoma of the esophagus were excluded.

\section{Data extraction}

The following data were carefully extracted from all eligible studies: the last name of first author, year of publication, trial phase, the number of participants, treatment regimens, ORR, PFS and OS with their HRs and 95\% CIs, and incidence of grade 3 or higher AEs.

Data extraction was done independently by two authors (BJK and JHK). If these two authors could not reach a consensus, other authors (HSK and HJJ) were consulted to resolve the disagreement.

\section{Statistical analysis}

Statistical values used in the meta-analysis were directly obtained from the original articles or were indirectly calculated from the given data. If HR and 95\% CI were not reported directly, the Engauge Digitizer version 9.1 was used to obtain the needed data from Kaplan-Meier curves. The effect size of RFS and OS was pooled through HR and its $95 \%$ CI. Heterogeneity among studies was estimated using the $R^{2}$ inconsistency test and chi-square-based Cochran's Q statistic test, and $P<0.1$ and $I^{2}>50 \%$ indicated the presence of significant heterogeneity. The fixed-effects model (Mantel-Haenszel method) was used to calculate the pooled HR and RR when substantial heterogeneity was not observed. When there was a substantial heterogeneity, we adopted the random-effects model (DerSimonian-Laird method). Final results were presented with HR or RR and 95\% CI. All reported $P$-values were two-sided, with $P<0.05$ defined as statistically significant. Statistical analyses were performed using the Review Manager 5.2 software [32]. The possibility of publication bias was assessed with the Egger's test [33] and visual inspection of the funnel plots [34].

\section{ACKNOWLEDGMENTS AND FUNDING}

This work was supported by Hallym University Research Fund 2015 (HURF-2015-38).

\section{CONFLICTS OF INTEREST}

All authors have declared no competing interest.

\section{REFERENCES}

1. Ferlay J, Soerjomataram I, Dikshit R, Eser S, Mathers C, Rebelo M, Parkin DM, Forman D, Bray F. Cancer incidence and mortality worldwide: sources, methods and major patterns in GLOBOCAN 2012. Int J Cancer. 2015; 136: 359-86.

2. Jung KW, Won YJ, Oh CM, Kong HJ, Lee DH, Lee KH; Community of Population-Based Regional Cancer Registries. Cancer statistics in Korea: incidence, mortality, survival, and prevalence in 2014. Cancer Res Treat. 2017; 49:292-305.

3. Siegel RL, Miller KD, Jemal A. Cancer statistics, 2016. CA Cancer J Clin. 2016; 66:7-30

4. Gunderson LL, Sosin H. Adenocarcinoma of the stomach: areas of failure in a reoperation series (second or symptomatic look) - clinicopathologic correlation and implications for adjuvant therapy. Int J Radiat Oncol Biol Phys. 1982; 8:1-11.

5. Wagner AD, Grothe W, Haerting J, Kleber G, Grothey A, Fleig WE. Chemotherapy in advanced gastric cancer: a systematic review and meta-analysis based on aggregate data. J Clin Oncol. 2006; 24:2903-9.

6. Cunningham D, Starling N, Rao S, Iveson T, Nicolson M, Coxon F, Middleton G, Daniel F, Oates J, Norman AR; Upper Gastrointestinal Clinical Studies Group of the National Cancer Research Institute of the United Kingdom. Capecitabine and oxaliplatin for advanced esophagogastric cancer. N Engl J Med. 2008; 358:36-46.

7. Zhang Z, Tang H, Lin J, Hu Y, Luo G, Luo Z, Cheng C, Wang P. Clinicopathologic and prognostic significance of human epidermal growth factor receptor in patients with gastric cancer: An updated meta-analysis. Oncotarget. 2017; 8:17202-15. https://doi.org/10.18632/oncotarget.15231.

8. Navarini D, Gurski RR, Madalosso CA, Aita L, Meurer L, Fornari F. Epidermal growth factor receptor expression in esophageal adenocarcinoma: relationship with tumor stage and survival after esophagectomy. Gastroenterol Res Pract. 2012; 2012:941954.

9. Van Cutsem E, Köhne CH, Láng I, Folprecht G, Nowacki MP, Cascinu S, Shchepotin I, Maurel J, Cunningham D, Tejpar S, Schlichting M, Zubel A, Celik I, et al. Cetuximab plus irinotecan, fluorouracil, and leucovorin as first-line treatment for metastatic colorectal cancer: updated analysis of overall survival according to tumor KRAS and BRAF mutation status. J Clin Oncol. 2011; 29:2011-19.

10. Douillard JY, Siena S, Cassidy J, Tabernero J, Burkes R, Barugel M, Humblet Y, Bodoky G, Cunningham D, Jassem J, Rivera F, Kocákova I, Ruff P, et al. Randomized, phase III trial of panitumumab with infusional fluorouracil, leucovorin, and oxaliplatin (FOLFOX4) versus FOLFOX4 alone as first-line treatment in patients with previously untreated metastatic colorectal cancer: the PRIME study. J Clin Oncol. 2010; 28:4697-705. 
11. Lorenzen S, Schuster T, Porschen R, Al-Batran SE, Hofheinz R, Thuss-Patience P, Moehler M, Grabowski P, Arnold D, Greten T, Müller L, Röthling N, Peschel C, et al. Cetuximab plus cisplatin-5-fluorouracil versus cisplatin5-fluorouracil alone in firstline metastatic squamous cell carcinoma of the esophagus: a randomized phase II study of the ArbeitsgemeinschaftInternistischeOnkologie. Ann Oncol. 2009; 20:1667-73.

12. Crosby T, Hurt CN, Falk S, Gollins S, Mukherjee S, Staffurth J, Ray R, Bashir N, Bridgewater JA, Geh JI, Cunningham D, Blazeby J, Roy R, et al. Chemoradiotherapy with or without cetuximab in patients with oesophageal cancer (SCOPE1): a multicentre, phase 2/3 randomised trial. Lancet Oncol. 2013; 14:627-37.

13. Dutton SJ, Ferry DR, Blazeby JM, Abbas H, Dahle-Smith A, Mansoor W, Thompson J, Harrison M, Chatterjee A, Falk S, Garcia-Alonso A, Fyfe DW, Hubner RA, et al. Gefitinib for oesophageal cancer progressing after chemotherapy (COG): A phase 3, multicentre, double-blind, placebo-controlled randomised trial. Lancet Oncol. 2014; 15:894-904.

14. Satoh T, Lee KH, Rha SY, Sasaki Y, Park SH, Komatsu Y, Yasui H, Kim TY, Yamaguchi K, Fuse N, Yamada Y, Ura T, Kim SY, et al. Randomized phase II trial of nimotuzumab plus irinotecan versus irinotecan alone as second-line therapy for patients with advanced gastric cancer. Gastric Cancer. 2015; 18:824-32.

15. Rao S, Starling N, Cunningham D, Sumpter K, Gilligan D, Ruhstaller T, Valladares-Ayerbes M, Wilke H, Archer C, Kurek R, Beadman C, Oates J.Matuzumab plus epirubicin, cisplatin and capecitabine (ECX) compared with epirubicin, cisplatin and capecitabine alone as first-line treatment in patients with advanced oesophago-gastric cancer: A randomised, multicentre open-label phase II study. Ann Oncol. 2010; 21:2213-9.

16. Lordick F, Kang YK, Chung HC, Salman P, Oh SC, Bodoky G, Kurteva G, Volovat C, Moiseyenko VM, Gorbunova V, Park JO, Sawaki A, Celik I, et al. Capecitabine and cisplatin with or without cetuximab for patients with previously untreated advanced gastric cancer (EXPAND): A randomised, open-label phase 3 trial. Lancet Oncol. 2013; 14:490-9.

17. Richards D, Kocs DM, Spira AI, David McCollum A, Diab S, Hecker LI, Cohn A, Zhan F, Asmar L. Results of docetaxel plus oxaliplatin (DOCOX) +/-cetuximab in patients with metastatic gastric and/or gastroesophageal junction adenocarcinoma: Results of a randomised Phase 2 study. Eur J Cancer. 2013; 49:2823-31.

18. Waddell T, Chau I, Cunningham D, Gonzalez D, Okines AF, Okines C, Wotherspoon A, Saffery C, Middleton G, Wadsley J, Ferry D, Mansoor W, Crosby T, et al. Epirubicin, oxaliplatin, and capecitabine with or without panitumumab for patients with previously untreated advanced oesophagogastric cancer (REAL3): a randomised, openlabel phase 3 trial. Lancet Oncol. 2013; 14:481-9.
19. Du F, Zheng Z, Shi S, Jiang Z, Qu T, Yuan X, Sun Y, Song Y, Yang L, Zhao J, Wang J, Chi Y. S-1 and cisplatin with or without nimotuzumab for patients with untreated unresectable or metastatic gastric cancer: a randomized, open-label phase 2 trial. Medicine (Baltimore). 2015; 94:e958.

20. Tebbutt NC, Price TJ, Ferraro DA, Wong N, Veillard AS, Hall M, Sjoquist KM, Pavlakis N, Strickland A, Varma SC, Cooray P, Young R, Underhill C, et al. Panitumumab added to docetaxel, cisplatin and fluoropyrimidine in oesophagogastric cancer: ATTAX3 phase II trial. Br J Cancer. 2016; 114:505-9.

21. Li A, Huang X, Song Y, Chen X, Sun J, Xu H, Wang Z. Anti-epidermal growth factor receptor-targeted therapy in upper gastrointestinal tract cancers: a meta-analysis. Growth Factors. 2015; 33:113-27.

22. Ciliberto D, Staropoli N, Caglioti F, Gualtieri S, Fiorillo L, Chiellino S, De Angelis AM, Mendicino F, Botta C, Caraglia M, Tassone P, Tagliaferri P. A systematic review and meta-analysis of randomized trials on the role of targeted therapy in the management of advanced gastric cancer: Evidence does not translate? Cancer Biol Ther. 2015; 16:1148-59.

23. Ku GY, Haaland BA, de Lima Lopes G Jr. Cetuximab in the firstline treatment of K-ras wild-type metastatic colorectal cancer: the choice and schedule of fluoropyrimidine matters. Cancer Chemother Pharmacol. 2012; 70:231-8.

24. Maughan TS, Adams RA, Smith CG, Meade AM, Seymour MT, Wilson RH, Idziaszczyk S, Harris R, Fisher D, Kenny SL, Kay E, Mitchell JK, Madi A, et al. Addition of cetuximab to oxaliplatin-based first-line combination chemotherapy for treatment of advanced colorectal cancer: Results of the randomised phase 3 MRC COIN trial. Lancet. 2011; 377:2103-14.

25. Bettstetter M, Berezowska S, Keller G, Walch A, Feuchtinger A, Slotta-Huspenina J, Feith M, Drecoll E, Höfler H, Langer R. Epidermal growth factor receptor, phosphatidylinositol-3-kinase catalytic subunit/PTEN, and KRAS/NRAS/BRAF in primary resected esophageal adenocarcinomas: loss of PTEN is associated with worse clinical outcome. Hum Pathol. 2013; 44:829-36.

26. Lordick F, Luber B, Lorenzen S, Hegewisch-Becker S, Folprecht G, Wöll E, Decker T, Endlicher E, Röthling N, Schuster T, Keller G, Fend F, Peschel C. Cetuximab plus oxaliplatin/leucovorin/5-fluorouracil in first-line metastatic gastric cancer: a phase II study of the Arbeitsgemeinschaft Internistische Onkologie (AIO). Br J Cancer. 2010; 102:500-5.

27. Moehler M, Mueller A, Trarbach T, Lordick F, Seufferlein T, Kubicka S, Geissler M, Schwarz S, Galle PR, Kanzler S. German Arbeitsgemeinschaft Internistische Onkologie. Cetuximab with irinotecan, folinic acid and 5-fluorouracil as first-line treatment in advanced gastroesophageal cancer: a prospective multi-center biomarker-oriented phase II study. Ann Oncol. 2011; 22:1358-66. 
28. Han SW, Oh DY, Im SA, Park SR, Lee KW, Song HS, Lee NS, Lee KH, Choi IS, Lee MH, Kim MA, Kim WH, Bang YJ, Kim TY. Phase II study and biomarker analysis of cetuximab combined with modified FOLFOX6 in advanced gastric cancer. Br J Cancer. 2009; 100:298-304.

29. Luber B, Deplazes J, Keller G, Walch A, Rauser S, Eichmann M, Langer R, Höfler H, Hegewisch-Becker S, Folprecht G, Wöll E, Decker T, Endlicher E, et al. Biomarker analysis of cetuximab plus oxaliplatin/ leucovorin/5-fluorouracil in first-line metastatic gastric and oesophago-gastric junction cancer: results from a phase II trial of the Arbeitsgemeinschaft Internistische Onkologie (AIO). BMC Cancer. 2011; 11:509.

30. Douillard JY, Pirker R, O’Byrne KJ, Kerr KM, Störkel S, von Heydebreck A, Grote HJ, Celik I, Shepherd FA. Relationship between EGFR expression, EGFR mutation status, and the efficacy of chemotherapy plus cetuximab in FLEX study patients with advanced non-small-cell lung cancer. J Thorac Oncol. 2014; 9:717-24.
31. Panic N, Leoncini E, de Belvis G, Ricciardi W, Boccia S. Evaluation of the endorsement of the preferred reporting items for systematic reviews and meta-analysis (PRISMA) statement on the quality of published systematic review and meta-analyses. PLoS One. 2013; 8:e83138.

32. Moher D, Cook DJ, Eastwood S, Olkin I, Rennie D, Stroup DF. Improving the quality of reports of meta-analyses of randomized controlled trials: the QUOROM statement. Onkologie. 2000; 23:597-602.

33. Eagger M, Davey Smith G, Schneider M, Minder C. Bias in meta-analysis detected by a simple graphical test. BMJ. 1997; 315:629-34.

34. Sterne JA, Sutton AJ, Ioannidis JP, Terrin N, Jones DR, Lau J, Carpenter J, Rücker G, Harbord RM, Schmid CH, Tetzlaff J, Deeks JJ, Peters J, et al. Recommendations for examining and interpreting funnel plot asymmetry in meta-analyses of randomised controlled trials. BMJ. 2011; 343:d4002. 